\title{
Solvent-Dependent Regioselective Oxidation of trans-Chalcones using Aqueous Hydrogen Peroxide
}

\author{
Peng Wang, ${ }^{a}$ Jin Cai, ${ }^{b}$ Jiabin Yang, ${ }^{a}$ Chunlong Sun, ${ }^{b}$ Lushen $\mathrm{Li}^{a}$ and Min Ji*,b \\ ${ }^{a}$ School of Biological Science and Medical Engineering and ${ }^{b}$ School of Chemistry and Chemical \\ Engineering, Southeast University, Nanjing 210096, P. R. China
}

\begin{abstract}
Um novo método para oxidação regiosseletiva de trans-chalconas com peróxido de hidrogênio em acetonitrila para fornecer ácidos cinâmicos é reportado. Somente os ácidos trans- $\beta$-arilacrílicos foram obtidos. Um largo intervalo de produtos funcionalizados pode ser efetivamente produzido a partir de várias chalconas com rendimentos de bons a excelentes.
\end{abstract}

A novel method for regioselective oxidation of trans-chalcones with hydrogen peroxide in acetonitrile to afford cinnamic acids is reported. Only trans- $\beta$-arylacrylic acids were observed. A wide range of functionalized products can be effectively produced from various chalcones in good to excellent yields.

Keywords: cinnamic acid, chalcone, regioselective, solvent-dependent

\section{Introduction}

The oxidation reaction, especially that of $\alpha, \beta$-unsaturated ketones is an important method for the conversion of functional groups in organic synthesis. ${ }^{1-4}$ Hydrogen peroxide is an environmentally benign oxidant as the only by-product after oxidation is water. ${ }^{5,6} \alpha, \beta$-Unsaturated ketones can be oxidized to various oxidation products by hydrogen peroxide in different reaction conditions, ${ }^{7,8}$ including products of oxygen insertion and epoxidation reactions. However, few reports mention that $\alpha, \beta$-unsaturated acids can be obtained from $\alpha, \beta$-unsaturated ketones using hydrogen peroxide as the oxidant.

Arylacrylic acids especially cinnamic acids are useful and versatile intermediates in organic synthesis, which can be used in flavors, synthetic indigo and certain pharmaceuticals. ${ }^{9-11}$ Several methods have been reported in the literature for the synthesis of cinnamic acids. Currently, they are commonly obtained by two methods: (i) the reaction of various benzaldehydes with malonic acid in the presence of different catalysts such as pyridine, piperidine and others; ${ }^{12,13}$ (ii) palladium-catalyzed Heck reaction of aryl halides and acrylic acid. ${ }^{14,15}$ But these reactions are of some disadvantages such as being sensitive to water or oxygen. Dakin oxidation, which can convert

*e-mail: jimin@ seu.edu.cn 2-hydroxybenzaldehyde or 4-hydroxybenzaldehyde to benzenediol, has been commonly used in the synthesis of phenols. However, to the best of our knowledge, access of arylacrylic acids by the Dakin oxidation has not been reported to date. Herein, it is reported a unique and highly selective of chalcones using $\mathrm{K}_{2} \mathrm{CO}_{3}$ as base in acetonitrile under mild conditions, and versatile arylacrylic acids are directly formed from chalcones in good yields and with excellent regioselectivities.

Tanaka et al. ${ }^{16}$ recently reported that 2'-hydroxychalcones can be oxidized to flavanols in a water suspension medium and have better yields than in an ethylenediaminedioxane system, while in acetone-water, the epoxides were obtained as the main products. ${ }^{17,18}$ Our group envisioned that solvents might play an important role in the oxidation of chalcones and potentially alter product distribution.

\section{Results and Discussion}

To test this hypothesis, our group started the study on the oxidation of 2'-hydroxychalcone (1a) in the presence of the $\mathrm{K}_{2} \mathrm{CO}_{3}-\mathrm{H}_{2} \mathrm{O}_{2}$ system at room temperature. To our delight, the oxidation of 2'-hydroxychalcone indeed afforded cinnamic acid in $90 \%$ yield in acetonitrile.

In order to elucidate the influence of the solvents, several solvents were examined for the oxidation of 2'-hydroxychalcone with hydrogen peroxide. Table 1 shows 
<smiles>O=C(/C=C/c1ccccc1)c1ccccc1O</smiles><smiles>CC(=O)OCC(=O)OCC(=O)O</smiles><smiles>O=C(O)/C=C/c1ccccc1</smiles>

Scheme 1. Oxidation of chalcones using aqueous hydrogen peroxide in acetonitrile. ${ }^{16}$

some of the results. From these experiments, it was found that trans-cinnamic acid was obtained in high conversion and good yield, employing $\mathrm{K}_{2} \mathrm{CO}_{3}$ as the base in acetonitrile at room temperature. Under this condition, pyrocatechol as the lost part of chalcone is not stable, ${ }^{19,20}$ and can be removed during the water washing step. On the other hand, no product was observed in toluene, dioxane and water. Ionic liquid $[\mathrm{bmim}]\left[\mathrm{BF}_{4}\right]$ used as solvent was also examined. ${ }^{21}$ However, traces of trans-cinnamic acid (2a) were observed even though $\mathrm{NaOH}$ was employed as the base. The Dakin oxidation of aromatic aldehydes using $\mathrm{H}_{2} \mathrm{O}_{2} / \mathrm{H}_{3} \mathrm{BO}_{3}$ in the presence of sulfuric acid was reported. ${ }^{22}$ However, it is ineffective for the oxidation of 1a.

Encouraged by these results, different alkali metal carbonates and organic base for the oxidation of 1a at room temperature were screened (Table 1). In contrast to $\mathrm{Na}_{2} \mathrm{CO}_{3}$, higher yield of $\mathbf{2 a}$ was observed employing $\mathrm{K}_{2} \mathrm{CO}_{3}$ as the base. The yield evidently went down from 90 to $79 \%$ when the amount of $\mathrm{K}_{2} \mathrm{CO}_{3}$ was reduced to half. However, the yields sharply decreased in $\mathrm{Cs}_{2} \mathrm{CO}_{3}$ and diethylamine conditions in which 3-hydroxyflavanone is the main byproduct. The application of $\mathrm{NaOH}$ had no obviously yield increase effect, except short reaction time. From an environmental point of view, it was employed $\mathrm{K}_{2} \mathrm{CO}_{3}$, an inexpensive and safe base, for following research.

With an optimized oxidation system in hand, it was then examined the generality of this protocol. As shown in Table 2, all reactions proceeded smoothly and afforded the desired products in good to excellent yields upon isolation. Notably, the halogen substituted chalcones needed more reaction time to afford the corresponding arylacrylic acids in good yields. Electron-withdrawing and electron-donating substituents on the benzene ring were also tolerated. For example, cinnamic acids with $o$-methoxy and $p$-methoxy groups can be obtained in favorably yields. The nitrosubstituted chalcones can be employed to produce the nitrocinnamic acids in excellent yields. It was observed that electron-withdrawing substrates exhibited more reactivity than electron-donating substrates. However, the dimethylamino group has little effect on the reactivity of reaction with a yield of $85 \%$. Interestingly, $(E)-3$-(benzo $[d]$ [1,3]dioxol-5-yl)acrylic acid can also be successfully prepared.

Table 1. Optimization of solvents and base for the oxidation of 2'-hydroxychalcone ${ }^{\text {a }}$

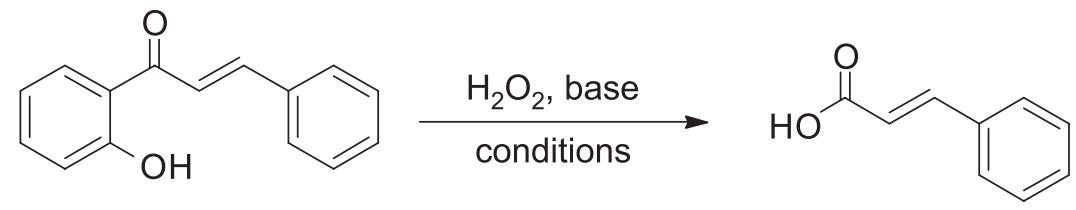

$1 \mathrm{a}$

$2 a$

\begin{tabular}{|c|c|c|c|c|}
\hline entry & Solvent & Base & time / h & Yield $^{\mathrm{b}} / \%$ \\
\hline 1 & toluene & $\mathrm{K}_{2} \mathrm{CO}_{3}$ & 24 & ND \\
\hline 2 & water & $\mathrm{K}_{2} \mathrm{CO}_{3}$ & 24 & ND \\
\hline 3 & dioxane & $\mathrm{K}_{2} \mathrm{CO}_{3}$ & 24 & ND \\
\hline 4 & {$[\mathrm{bmim}]\left[\mathrm{BF}_{4}\right]$} & $\mathrm{K}_{2} \mathrm{CO} 3$ & 12 & trace \\
\hline 5 & acetonitrile & $\mathrm{K}_{2} \mathrm{CO}_{3}$ & 5 & 90 \\
\hline 6 & acetonitrile & $\mathrm{Na}_{2} \mathrm{CO}_{3}$ & 5 & 60 \\
\hline 7 & acetonitrile & $\mathrm{Cs}_{2} \mathrm{CO}_{3}$ & 5 & 75 \\
\hline 8 & acetonitrile & $\mathrm{Et}_{2} \mathrm{NH}$ & 5 & 45 \\
\hline 9 & acetonitrile & $\mathrm{NaOH}$ & 1 & 90 \\
\hline 10 & {$[\mathrm{bmim}]\left[\mathrm{BF}_{4}\right]$} & $\mathrm{NaOH}$ & 12 & trace \\
\hline $11^{\mathrm{c}}$ & {$[\mathrm{bmim}]\left[\mathrm{BF}_{4}\right]$} & - & 12 & NR \\
\hline $12^{\mathrm{d}}$ & acetonitrile & $\mathrm{K}_{2} \mathrm{CO}_{3}$ & 12 & 79 \\
\hline
\end{tabular}

aReaction conditions: unless otherwise specified, all reactions were carried out with $1 \mathbf{1 a}(1 \mathrm{mmol})$, base $(10 \mathrm{mmol})$ and $30 \% \mathrm{H}_{2} \mathrm{O}_{2}(0.5 \mathrm{~mL})$ at room temperature; byield of isolated product $2 \mathrm{a}$; ' ${ }^{\text {using }} \mathrm{H}_{3} \mathrm{BO}_{3} / \mathrm{H}_{2} \mathrm{SO}_{4}$ (cat) instead of base; ${ }^{\mathrm{u}} \mathrm{using} 5 \mathrm{mmol} \mathrm{K}_{2} \mathrm{CO}_{3}$; ND: not determined; NR: no reaction. 
Table 2. Oxidation of various chalcones with hydrogen peroxide ${ }^{a}$<smiles>O=C(/C=C/Br)c1ccccc1O</smiles>
1

entry

2<smiles>Cc1ccc(Cl)cc1Cl</smiles>

$3^{c}$<smiles>Cc1ccc(F)cc1</smiles><smiles>Cc1ccccc1[N+](=O)[O-]</smiles>
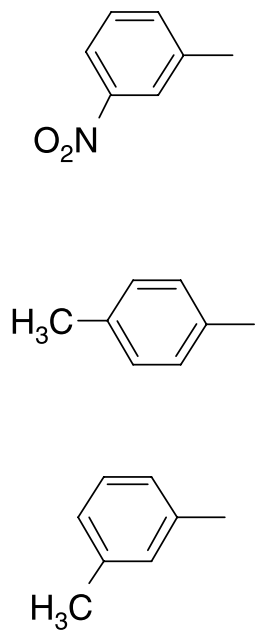

8

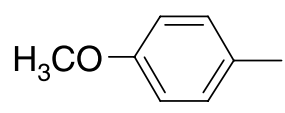

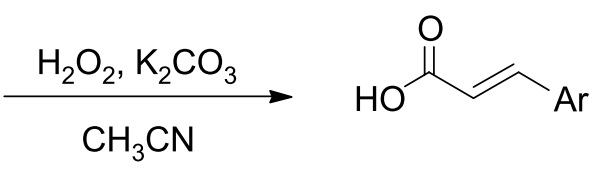

2

Product

Yield ${ }^{b} / \%$<smiles>O=C(O)/C=C/c1ccccc1</smiles>

$2 a$<smiles>O=C(O)/C=C/c1ccc(Cl)cc1Cl</smiles>

2b<smiles>O=C(O)/C=C/c1ccc(F)cc1</smiles>

2c<smiles>O=C(O)/C=C/c1ccccc1[N+](=O)[O-]</smiles>

2d<smiles>O=C(O)/C=C/c1cccc([N+](=O)[O-])c1</smiles>

91<smiles>Cc1ccc(/C=C/C(=O)O)cc1</smiles>

78

2g<smiles>COc1ccc(/C=C/C(=O)O)cc1</smiles>

80 
Table 2. continuation

\begin{tabular}{|c|c|c|c|}
\hline entry & $\mathrm{Ar}$ & Product & Yield $^{\mathrm{b}} / \%$ \\
\hline 9 & & $2 \mathbf{i}$ & 74 \\
\hline 10 & & 2j & 82 \\
\hline 11 & & 2k & 85 \\
\hline 12 & & 2 & 89 \\
\hline
\end{tabular}

${ }^{a}$ Reaction conditions: unless otherwise specified, all reactions were carried out with $\mathbf{1}(1 \mathrm{mmol}), \mathrm{K}_{2} \mathrm{CO}_{3}(10 \mathrm{mmol})$ and $30 \% \mathrm{H}_{2} \mathrm{O}_{2}(0.5 \mathrm{~mL})$ in $1 \mathrm{~mL}$ acetonitrile at room temperature for $5 \mathrm{~h}$; byield of isolated product; ' reaction time: $12 \mathrm{~h}$.

To understand this oxidation further, it was focused on the substituents on the other phenyl. Clearly, it can be found that the position of hydroxyl on this phenyl ring is critical for this transformation (Table 3). 2'-Hydroxy chalcone can afford the trans-cinnamic acid easily. Moreover, the methoxy group at 4'-position can promote this oxidation slightly. However, no product was obtained when hydroxyl was at the 3'-position or no hydroxyl existed.

Table 3. The synthesis of trans-cinnamic acid from various chalcones ${ }^{\mathrm{a}}$<smiles>[R]c1ccc(C(=O)/C=C/c2ccccc2)c([R])c1[R]</smiles>
1

$2 a$

\begin{tabular}{|c|c|c|c|c|c|}
\hline entry & $\mathrm{R}^{1}$ & $\mathrm{R}^{2}$ & $\mathrm{R}^{3}$ & time $/ \mathrm{h}$ & Yield $^{\mathrm{b}} / \%$ \\
\hline 1 & $\mathrm{OH}$ & $\mathrm{H}$ & $\mathrm{H}$ & 5 & 90 \\
\hline 2 & $\mathrm{OH}$ & $\mathrm{H}$ & $\mathrm{Cl}$ & 5 & 88 \\
\hline 3 & $\mathrm{H}$ & $\mathrm{OH}$ & $\mathrm{H}$ & 24 & NR \\
\hline 4 & $\mathrm{H}$ & $\mathrm{H}$ & $\mathrm{H}$ & 24 & NR \\
\hline 5 & $\mathrm{OH}$ & $\mathrm{H}$ & $\mathrm{OCH}_{3}$ & 4 & 91 \\
\hline 6 & $\mathrm{H}$ & $\mathrm{H}$ & $\mathrm{OH}$ & 6 & 87 \\
\hline 7 & $\mathrm{H}$ & $\mathrm{H}$ & $\mathrm{OCH}_{3}$ & 5 & 82 \\
\hline
\end{tabular}

aReaction conditions: unless otherwise specified, all reactions were carried out with $\mathbf{1}(1 \mathrm{mmol}), \mathrm{K}_{2} \mathrm{CO}_{3}(10 \mathrm{mmol})$ and $30 \% \mathrm{H}_{2} \mathrm{O}_{2}(0.5 \mathrm{~mL})$ in $1 \mathrm{~mL}$ acetonitrile at room temperature; byield of isolated product; NR: no reaction. 


\section{Experimental}

\section{General methods}

Nuclear magnetic resonance (NMR) spectra were recorded on a Bruker-300 $\mathrm{MHz}$ spectrometer. Chemical shifts are reported relative to TMS (tetramethylsilane), coupling constants are given in hertz. Melting points were measured on a WRS-2A melting point apparatus and are uncorrected. Commercial reagents were used as received. Analytical-grade solvents and commercially available reagents were used without further purification.

\section{General procedure}

To a $5 \mathrm{~mL}$ round bottom flask equipped with a stir bar, trans-2'-hydroxychalcone $\mathbf{1 a}(1 \mathrm{mmol}), \mathrm{K}_{2} \mathrm{CO}_{3}$ ( $1.38 \mathrm{~g}, 10 \mathrm{mmol}), 35 \% \mathrm{H}_{2} \mathrm{O}_{2}$ solution $(0.5 \mathrm{~mL})$ and $2 \mathrm{~mL}$ acetonitrile were added. The reaction was stirred at room temperature and monitored by TLC (thin layer chromatograph) until disappearance of the starting material. The solvent was evaporated with reduced pressure. To the residue, it was added $1 \mathrm{~mol} \mathrm{~L}^{-1}$ hydrochloric acid, the solid was filtered to afford 2a as white solid (133 $\mathrm{mg}, 90 \%)$; ${ }^{1} \mathrm{H}$ NMR (300 MHz, DMSO- $\left.d_{6}\right) \delta 7.58(\mathrm{~d}, 1 \mathrm{H}, J 16 \mathrm{~Hz})$, 7.42-7.69 (m, 5H), $6.53(\mathrm{~d}, 1 \mathrm{H}, J 16 \mathrm{~Hz}) ;{ }^{13} \mathrm{C}$ NMR $\left(300 \mathrm{MHz}, \mathrm{DMSO}-d_{6}\right) \delta 167.7,144.0,134.3,130.3,128.9$, 128.2, 119.3 .

\section{Conclusions}

In conclusion, it was reported a novel method for the regioselective oxidation of chalcones with hydrogen peroxide in acetonitrile to afford cinnamic acids, utilizing $\mathrm{K}_{2} \mathrm{CO}_{3}$ as the base. Only trans- $\beta$-arylacrylic acids were observed. A wide range of functionalized cinnamic acids can be effectively produced from various chalcones in good to excellent yields. Our group is convinced that this procedure is and will be of significant value for the synthesis of a variety of trans- $\beta$-arylacrylic acids, which are important for organic chemistry.

\section{Supplementary Information}

Supplementary data are available free of charge at http://jbcs.sbq.org.br as a PDF file.

\section{Acknowledgments}

This work is supported by the National Basic Research Program of P. R. China (No. 2011CB933503) and
Technology Supporting Program of Jiangsu province (BE2009639, BE2012657).

\section{References}

1. Adger, B. M.; Barkley, J. V.; Bergeron, S.; Cappi, M. W.; Flowerdew, B. E.; Jackson, M. P.; McCague, R.; Nugent, T. C.; Roberts, S. M.; J. Chem. Soc., Perkin Trans. 1 1997, 3501.

2. Bunton, C. A.; Minkoff, G. J.; J. Chem. Soc. 1949, 665.

3. Jakka, K.; Liu, J. ; Zhao, C.-G.; Tetrahedron Lett. 2007, 48, 1395.

4. Lu, X.; Liu, Y.; Sun, B.; Cindric, B.; Deng, L.; J. Am. Chem. Soc. 2008, 130, 8134.

5. Gallo, R. D. C.; Gebara, K. S.; Muzzi, R. M.; Raminelli, C.; J. Braz. Chem. Soc. 2010, 21, 770.

6. Alizadeh, M. H.; Tayebee, R.; J. Braz. Chem. Soc. 2005, 16, 108.

7. Yamaguchi, K.; Mori, K.; Mizugaki, T.; Ebitani, K.; Kaneda, K.; J. Org. Chem. 2000, 65, 6897.

8. Levine, S. D.; J. Org. Chem. 1966, 31, 3189.

9. Singh, T. S.; Mitra, S.; Spectrochim. Acta, Part A 2011, 78, 942.

10. Brožič, P.; Golob, B.; Gomboc, N.; Rižner, T. L.; Gobec, S.; Mol. Cell. Endocrinol. 2006, 248, 233.

11. Adisakwattana, S.; Sookkongwaree, K.; Roengsumran, S.; Petsom, A. ; Ngamrojnavanich, N.; Chavasiri, W.; Deesamer, S.; Yibchok-anun, S.; Bioorg. Med. Chem. Lett. 2004, 14, 2893.

12. Khosropour, A. R.; Khodaei, M. M.; Moghanian, H.; J. Chem. Res. 2005, 364.

13. Mitra, A. K.; De, A.; Karchaudhuri, N.; Synth. Commun. 1999, 29, 573.

14. Plevyak, J. E. ; Dickerson, J. E. ; Heck, R. F. ; J. Org. Chem. 1979, 44, 4078.

15. Tang, Y.-Q.; Chu, C.-Y. ; Zhu, L.; Qian, B.; Shao, L.-X.; Tetrahedron 2011, 67, 9479.

16. Tanaka, K.; Sugino, T.; Green Chem. 2001, 3, 133.

17. Husain, A.; Shaharyar, M.; Asian J. Chem. 2005, 17, 624.

18. Krow, G. R.; Org. React. 1993, 43, 251.

19. Brecht, E. A.; Rogers, C. H.; J. Am. Pharm. Assoc. 1940, $29,178$.

20. Wieland, H.; Franke, W.; Justus Liebigs Ann. Chem. 1927, 457,1 .

21. Zambrano, J. L.; Dorta, R.; Synlett 2003, 1545.

22. Roy, A.; Reddy, K. R.; Mohanta, P. K.; Ila, H.; Junjappa, H.; Synth. Commun. 1999, 29, 3781.

Submitted: August 28, 2012 Published online: March 15, 2013 